steroidal anti-inflammatory drug-induced small intestinal strictures. Gastroenterology 1988;94:1070-4.

11 Ukabam SO, Homeida MA, Cooper BT. Small intestinal permeability in Sudanese subjects: evidence of tropical enteropathy. Trans $R$ Soc Trop Med Hyg 1986;80:204-7.

12 Behrens R, Northrop C, Lunn P, Neale G, Hanlon P. Factors affecting the integrity of intestinal mucosa in Gambian children. Proc Nutr Soc 1986; 45:67a.

13 Peled Y, Watz C, Gilat T. Measurement of intestinal permeability using ${ }^{31}$ CrEDTA Am f Gastroenterol 1985;80:770-3.

14 Casellas F, Aguadé S, Soriano B, Accarino A, Molero J, Guarner L. Intestinal permeability to ${ }^{\infty} \mathrm{Tc}$ diethylene-tetraaminopentaacetic acid in inflammatory bowel disease. Am $\mathcal{f}$ Gastroenterol 1986;81:767-70.

15 Auer IO, Habscheid W, Hiller S, Gerhards W, Eilles C. Nicht-steroidale antiphlogistika Erhöhen die Darmpermeabilität. Dtsch Med Wochensch 1987; 112:1032-7.

16 Ruppin H, Hotze A, Düring A, et al. Reversible Funktions-Sjörungen de Intestinaltraktes durch abdominelle Strahlentherapie. Z Gastroenterol 1987 25:261-9.

17 Leclercq-Foucart J, Forget P, Sodoyez-Goffaux F, Zappitelli A. Intestinal permeability to "CrEDTA in children with cystic fibrosis. I Pedia Gastroenterol Nutr 1986;5:384-7.

18 Leclercq-Foucart J, Forget P, Van Cutsem JL. Lactulose-rhamnose intestinal permeability in children with cystic fibrosis. $\mathcal{F}$ Pediat Gastroenterol Nutr 1987;6:66-70.

19 Turck D, Ythier H, Maquet E, et al. Intestinal permeability to "CrEDTA in children with Crohn's disease and coeliac disease. $\mathcal{F}$ Pediatr Gastroent Nutr 1987;6:535-7.

20 Jenkins RT, Rooney PJ, Jones DB, Bienenstock J, Goodacre RL. Increased intestinal permeability in patients with rheumatoid arthritis: a side effect of oral non-steroidal anti-inflammatory drug therapy. $\mathrm{Br} \mathcal{J}$ Rheumato 1987;26:103-7.

21 Jenkins RT, Jones DB, Goodacre RL, et al. Reversibility of increased intestinal permeability to ${ }^{\mathrm{S}} \mathrm{CrEDTA}$ in patients with gastrointestina inflammatory bowel disease. Am $\mathcal{f}$ Gastroenterol 1987;82:1159-64.

22 O'Morain CA, Abelow AC, Chervli LR, Fleischner GM, Das KM. 'CrEDTA test: a useful test in the assessment of inflammatory bowel disease. $\mathcal{f} L a b$ Clin Med 1986;108:430-5.
23 Hetzel DAS, Labrody JT, Bellon M, et al. The "CrEDTA absorption test in coeliac patients treated with a gluten free diet. International Research Communication fournal of Medical Science 1986;14:1183-4.

24 Bjarnason I, Peters TJ, Veall N. 'CrEDTA test for intestinal permeability. Lancet 1984;ii:523.

25 Bjarnason I, Williams P, Smethurst P, Peters TJ, Levi AJ. Effect of nonsteroidal anti-inflammatory drugs and prostaglandins on permeability of the human small intestine, Gut 1986;27:1292-7.

26 Bjarnason I, Ward K, Peters TJ. The leaky gut of alcoholism: possible route of entry for toxic compounds. Lancet 1984; i: 179-82.

27 Menzies IS, Mount JN, Wheeler MJ. Quantitative estimation of clinically important monosaccharides in plasma by rapid thin-layer chromatography. Ann Clin Biochem 1978;15:65-76.

28 Chadwick VS, Phillips SF, Hofmann AF. Measurements of intestinal permeability using low molecular weight polyethyleneglycols (PEG 400). II Application to normals and abnormal permeability states in man and animals. Gastroenterology 1977;73:247-51

29 Kumar D, Wingate DL. The irritable bowel syndrome; a paroxysmal motor disorder. Lancet 1985;ii:973-7.

30 Baker SJ. Geographical variations in the morphology of the small intestinal mucosa in apparently healthy individuals. Pathologia et Microbiologia 1973;39:222-37

31 Baker SJ, Mathan VI. Syndrome of tropical sprue in south India. Am $\mathrm{f}$ Clin Nutr 1968;21:984-93.

32 Brunser O, Eidelman S, Kupstein FA. Intestinal morphology of rura Haitians. A comparison between overt tropical sprue and asymptomatic subjects. Gastroenterology 1970;58:655-68.

33 Schenk EA, Klipstein FA, Tomasini JT. Morphological characteristics of jejunal biopsies from asymptomatic Haitians and Puerto Ricans. Am $\mathrm{f} \mathrm{Clin}$ Nutr 1972;25:1080-3.

34 Cooke WJ, Holmes GKT. The jejunal mucosa. In: Cook WJ, Holmes GKT, eds. Coeliac disease. Edinburgh: Churchill Livingstone, 1984:23-66.

35 Lindenbaum J, Harmon JW, Gerson CD. Subclinical malabsorption in developing countries. Am f Clin Nutr 1972;25:1056-106.

36 O'Mahoney CP, Stevens FM, Bourke M, McCarthy CF, Weir DB, Feighery CF. 'CrEDTA test for coeliac disease. Lancet 1984;i:1354-5.

37 Mylotte M, Egan-Mitchell B, McCarthy CF, McNicholl B. Incidence of coeliac disease in the west of Ireland. Br Med f 1973;i:703-5.

\section{A place in the sun?}

\section{Izhar Ben-Shlomo, Geoffrey Goodman}

The number of original medical articles is ever increasing, and evaluation of trends may contribute to understanding the nature of medical progress. An increase in the number of authors per article is well recognised, as is the increasing number of references. We report a statistical analysis in which we compared certain aspects of articles, such as length of title and number of authors, in three medical journals in 1955 and 1985. We also carried out a longitudinal study of a representative number of articles published during January in the British Medical fournal during 1955-85.

\section{Method and results}

We chose three journals, the Lancet, Circulation, and Fertility and Sterility, representing disparate aspects of medical literature, and selected from each between 43 and 57 consecutive articles from 1955 and 1985 . Only 43 articles were published in Fertility and Sterility in 1955, and, accordingly, we chose articles from the middle of the year in 1985. Articles in the Lancet (original contributions and preliminary communications) and Circulation were taken from the beginning of the two years. The variables analysed were the number of words in the title and the number of authors, references, and pages. Adjustment was made for the change in format of Fertility and Sterility; the other two

Survey of articles published in three medical journals in 1955 and 1985. Values are medians (95\% confidence intervals)

\begin{tabular}{|c|c|c|c|c|c|c|}
\hline & \multicolumn{2}{|c|}{ Lancet } & \multicolumn{2}{|c|}{ Circulation } & \multicolumn{2}{|c|}{ Fertility and Sterility } \\
\hline & $1955(n=43)$ & $1985(n=57)$ & $1955(n=48)$ & $1985(n=51)$ & $1955(n=47)$ & $1985(n=48)$ \\
\hline $\begin{array}{l}\text { No of words in title } \\
\text { No of authors } \\
\text { No of references } \\
\text { No of pages }\end{array}$ & $\begin{array}{c}7(6 \text { to } 8) \\
2(1 \text { to } 2) \\
8(5 \text { to } 11) \\
2 \cdot 3(1 \cdot 4 \text { to } 3 \cdot 2)\end{array}$ & $\begin{array}{c}10(9 \text { to } 12)^{\star} \\
4 \cdot 5(3 \text { to } 5)^{\star} \\
19(16 \text { to } 21)^{\star} \\
2 \cdot 3(2 \cdot 1 \text { to } 2 \cdot 5)\end{array}$ & $\begin{array}{c}12(10 \text { to } 13) \\
3(3 \text { to } 3) \\
16 \cdot 5(13 \text { to } 21) \\
8 \cdot 0(7 \cdot 0 \text { to } 10 \cdot 0) \dagger\end{array}$ & $\begin{array}{c}15(14 \text { to } 18) \dagger \\
5(5 \text { to } 6)^{\star} \\
24(22 \text { to } 30)^{\star} \\
7 \cdot 0(5 \cdot 7 \text { to } 7 \cdot 5)\end{array}$ & $\begin{array}{c}9(6 \text { to } 10) \\
1(1 \text { to } 2) \\
9(6 \text { to } 12) \\
4 \cdot 3(3 \cdot 3 \text { to } 5 \cdot 3) \ddagger\end{array}$ & $\begin{array}{c}13(11 \text { to } 15)^{\star} \\
4(4 \text { to } 5)^{\star} \\
18(16 \text { to } 21)^{\star} \\
4 \cdot 5(4.0 \text { to } 4.5)\end{array}$ \\
\hline
\end{tabular}

${ }^{\star} \mathrm{p}<0.001 .+\mathrm{p}<0 \cdot 01 . \ddagger$ Adjusted for change in format of journal. journals maintained their format. The results were analysed with the Mann-Whitney $U$ test, regression analysis, and rank correlation.

To check for the continuity of trends identified the first 10 full articles that appeared every year in the $B M \mathcal{F}$ were similarly analysed, and the median values were calculated.

In all three journals the titles of the articles were longer and the numbers of authors and references were larger in 1985 than in 1955 (table). The numbers of words in the titles were significantly correlated with the numbers of authors $(p<0.05)$ but not with the other variables. The change in the number of pages was more limited, with a small but significant reduction in that of Circulation in $1985(\mathrm{p}<0.01)$.

In the $B M f$ there was a highly significant and consistent yearly increase in the number of words per title (Spearman's correlation coefficient $=0.59(95 \%$ confidence interval 0.30 to $0.78 ; \mathrm{p}<0.001)$ ) and in the number of authors accredited per article $(0.82(0.65$ to $0.91 ; \mathrm{p}<0.001)$, confirming the trends identified previously.

\section{Comment}

One reason why titles have become longer may be the increasing complexity of medicine. On this basis,
Izhar Ben-Shlomo, MD, senior registrar

\section{Amrad (Research and Development), Amiad, Hevel Korazim, \\ Israel 12335 \\ Geoffrey Goodman, PHD, scientific director}

Correspondence to: Dr I Ben-Shlomo, Amiad, Hevel Korazim, Israel 12335. 
however, longer articles might be expected, but we found no supporting evidence. This may suggest that editors are trying to include more contributions in the available space. Alternatively, narrowing the range of material covered or reporting less experimental work in a given article may be responsible, perhaps a reflection of "publish or perish." These factors, together with the rising number of journals, may place increasing pressure on the interested reader, who may not find time for adequate consideration, even of abstracts. Could it be, then, that the longer titles are an attempt to draw attention to the kernel of the material in a sort of mini abstract? This might be valuable in attracting the more marginal attention of staff working in adjacent but less related disciplines. Computerised searching based on key words, which in some cases includes a search only within the title, may also encourage this trend.

Could there, however, be another explanation? The correlation between the length of title and the number of authors but not with the other variables raises a question. Substantive discussion among the increasing number of authors per article might have been expected to lead to longer articles influenced by a greater diversity of viewpoints. This is not the case. Our evidence questions whether active contribution by some participants is reserved for the title, which alone bears the thumbprint of all.

\title{
The haggis tolerance test in Scots and Sassenachs
}

\author{
Alan G Fraser, Alan Rees, Stephanie Matthews, Geraint T Williams
}

\section{Departments of}

Cardiology, Medicine, Medical Biochemistry, and Pathology, University Hospital of Wales, Cardiff CF4 4XN

Alan G Fraser, MRCP, senior registrar

Alan Rees, MRCP, lecturer

Stephanie Matthews, MRCPATH,

senior registrar

Geraint T Williams,

MRCPATH, senior lecturer

Correspondence to: $\operatorname{Dr}$ A G Fraser, Department of Echocardiography,

Thoraxcentrum Ba 302, Dijkzigt Hospital, 3000 DR

Rotterdam, The

Netherlands.

\begin{abstract}
To find out if the Scottish national dish, haggis, contributes to the high incidence of coronary heart disease in Scotland the lipaemic effect of a meal of $200 \mathrm{~g}$ of haggis was measured in six Scottish and 10 Sassenach men. The Scots had higher fasting cholesterol and triglyceride concentrations and a lower proportion of high density lipoprotein cholesterol than the Sassenachs. Four subjects were found to have hyperlipoproteinaemia, which had been unrecognised previously. Serum cholesterol concentrations did not change after haggis was eaten (mean dose $2.6 \mathrm{~g} / \mathrm{kg}$ body weight). Serum concentrations of triglycerides increased by $51 \%$ at 90 minutes in the Sassenachs but were unaltered in the Scots. There were.no serious adverse effects.

This study shows that Scots have higher lipid concentrations than Sassenachs but seem to be resistant to the lipaemic effect of haggis. The haggis tolerance test may be useful in Sassenachs.
\end{abstract}

\section{Introduction}

Coronary heart disease is now the main cause of death in Scotland. One important contributing factor is consumption of fat, but, strangely, the influence of the Scottish national dish, haggis, on blood lipid concentrations and heart disease seems to have been neglected as a subject for serious scientific inquiry.

We are aware of only two previous medical investi-

assigned according to the country of birth of both parents.

Ethical approval was not sought, and informed consent could not be obtained as so little is known about the consequences of eating haggis. There was no control group because we deemed it unethical to withhold haggis from any subject.

After the subjects had fasted overnight and abstained from alcohol blood samples were taken for measurement of fasting lipid concentrations. All subjects then ate $200 \mathrm{~g}$ of freshly boiled haggis (T G Willis, Edinburgh) as their breakfast. Their compliance was ensured by all subjects eating together. Apple or orange juice was permitted to help swallowing, but whisky was withheld until the end of the study. Blood samples were taken 30 and 90 minutes after the last mouthful of haggis. Subjects were given diaries in which to record any unwanted symptoms.

The haggis that we used is commercially available and prepared in bulk ( 0.5 tonnes a week) according to traditional recipes. ${ }^{2}$ Its ingredients are lambs' pluck (heart and lung), pigs' liver, beef suet (perinephric fat), and pinhead (coarse) oatmeal. These are cooked; minced; seasoned with salt, black pepper, coriander, and ginger; and boiled in a sheep's paunch (stomach). A $200 \mathrm{~g}$ portion of haggis contains $21.4 \mathrm{~g}$ protein, $43.4 \mathrm{~g}$ fat, $38.4 \mathrm{~g}$ carbohydrate, $5 \%$ inedible fibre, and $2584 \mathrm{~kJ}$. $^{3}$

Quality was checked by performing histological studies on a generous wedge biopsy specimen excised from a randomly selected haggis (fig 1). Electron formed by Professor Horst Oertel at McGill University in 1929 confirmed that haggis consists of degenerate liver cells and cereal products within a sac lined by epithelial and muscle tissue ( $\mathrm{R}$ Cameron, personal communication). A paper delivered to the Nutrition Society extolled the virtues of haggis, turnips, and potatoes as a healthy and balanced diet. ${ }^{\prime}$ An exhaustive search of publications produced no other studies, and haggis is not cited in Index Medicus. We therefore set up the Cardiff heart, alveoli, gut and grain ingestion study (HAGGIS) to investigate the effects of consumption of haggis on blood lipid concentrations.

\section{Subjects and methods}

We studied 16 healthy male volunteers (that is, conscripted medical colleagues), including six expatriate Scots and 10 Sassenachs. Their mean age was 36 ( $95 \%$ confidence interval 31 to 41 ). Nationality was

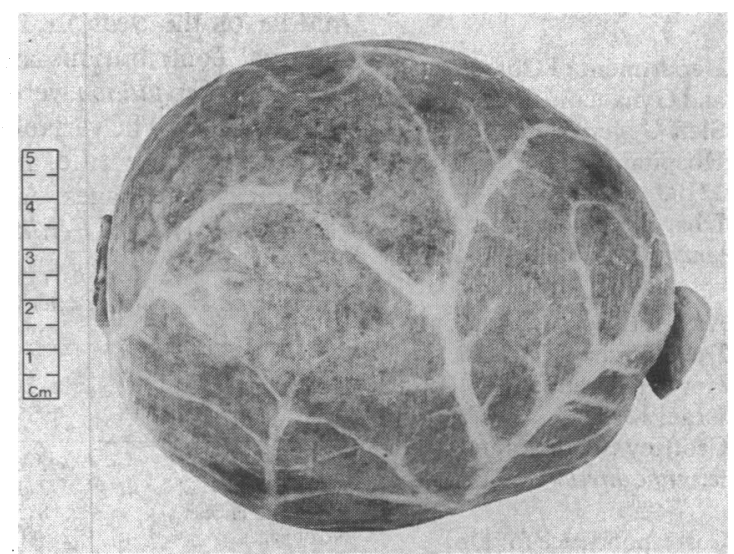

FIG 1-Haggis, cold and before gastrotomy, showing gastric blood vessels 